\title{
ADIPOBIOLOGY OF THE BRAIN: FROM BRAIN DIABETES TO ADIPOSE ALZHEIMER'S DISEASE
}

\author{
Luigi Aloe' ${ }^{1}$ Anton B. Tonchev², Alexander Maucher², Marco Fiore', Marin D. Zhelezov², \\ and George N. Chaldakov ${ }^{2}$
}

'Institute of Cell Biology and Neurobiology, National Research Council (CNR) Rome, Italy and ${ }^{2}$ Laboratory of Cell Biology, Department of Anatomy and Histology, Medical University, Varna, Bulgaria

\section{Introduction}

Accumulating evidence suggests that brain-adipose tissue bidirectional communications might be promising intervention point for cardiometabolic and neurodegenerative diseases (1). Alzheimer's disease $(\mathrm{AD})$ is a progressive and yet incurable disorder characterized by memory loss and cognitive ability deterioration. It is the most common form of dementia, afflicting millions of humans globally. Although the progression of $\mathrm{AD}$ currently cannot be stopped or reversed, an increased understanding of its pathogenesis may give patients and their families chance for new therapies, which may at least delay the progress of the disease.

Although the human brain is nearly 50 percent lipids, the brain is the only organ which does not contain adipose tissue, except that located at the parasellar region, traditionally known as the cavernous sinus (Weninger WJ, Pramhas D. J Anat 2000; 197 (Pt 4): 681-686; Weninger WJ, Prokop M. Clin Anat 2004;17:112-117).

Today, we know that essential fatty acids, particularly the omega-3 fatty acids and decosahexaenoic acid (DHA), play important role for brain development and are among the most crucial molecules that determine a large spectrum of brain's functions (for brain GPR40, a receptor for free fatty acids, see Tonchev et al in the section "Abstracts from $4^{\text {th }}$ ISAA" published in this volume of Adipobiology).
To maintain metabolic and anthropometric homeostasis, the brain must precisely monitor the peripheral energy state. This monitoring is also extremely important for the brain's survival, because the brain does not store energy but depends solely on a continuous supply of nutrients from the blood circulation.

Brain-adipose misunderstanding may lead to various metabolic diseases including obesity, type 2 diabetes mellitus, metabolic syndrome and AD. Here we Dance Round the hypothesis of brain diabetes and adipose $A D$, white adipose tissue (WAT) being in the scope of the hypothesis.

\section{Neuroadipocrinology}

Both phenotypes of human life, the health and the disease, require the interaction between the cells of nervous system and the cells of other systems. One of the biggest recent achievements of neurobiology and adipobiology is the study on neurotrophic factors, e.g. nerve growth factor (NGF) and brain-derived neurotrophic factor (BDNF) (2-4), insulin-like growth factor-1 (5), and adipokines, e.g. leptin, adiponectin, resistin and apelin (610; 11 for adipose-derived NGF and BDNF).

As often occurs, the framework of an initial concept of the role of newly discovered molecules extends in the light of emerging findings. This was also the case with neurotrophic factors and adipokines. For instance, for some 30 years after the discovery of NGF, there have been few hints to indicate that it may act

Received 3 December 2015, revised 8 December 2015, accepted 12 December 2015. 
on non-neuronal cells. Thus, it was remarkable when Aloe and Levi-Montalcini have discovered in 1977 that the treatment of newborn rats with NGF caused a systemic increase in the number of mast cells. This seminal finding paved the road of a novel research field, the neuroimmunology (12).

In the same context, the adipose tissue is no more considered mostly a lipid storage but a dynamic endocrine and paracrine organ producing a dazzling number of signaling proteins collectively termed adipokines (6). Currently, their number estimated to be over 600 (7). Some of them mediate the cross-talk between adipose tissue and brain in regulating food intake and energy homeostasis. However, the brain (mostly hypothalamus) is not the only target for leptin and other adipokines, as well as the food intake is not the only biological effect of these adipokines. Rather, some adipokines support various metabolic and cognitive functions and exert both metabo- and neurotrophic actions (13-24). Current data of adipose-derived neuroendocrine and neurotrophic factors are summarized in Tables 1,2 . This raises an intriguing question as to whether adipose tissue might be a peripheral counterpart of hypothalamus-hypophysis, a part of diffuse neuroendocrine system, or our third brain (Obesity Metab 2009; 5: 94-96). Cumulatively, linking neurobiology and adipobiology resulted in neuroadipocrinology, a novel component of neuroendocrinology (Cell Biol Int 2010; 34:1051-1053).

\section{From brain diabetes to adipose Alzheimer's disease}

Epidemiological evidence supports the observation that subjects with type 2 diabetes mellitus are at higher risk to develop AD. An estimated 312 million people suffer from type 2 diabetes while AD affects nearly 45 million people worldwide. Whether and how these two diseases are causally linked is not yet known.

Adipose tissue and brain of high fat diet fed animals expressed increased levels of proinflammatory cytokines and macrophage activation. Noteworthy, both brain and adipose tissue also have elevated amyloid precursor protein (APP) levels. Indeed, obesity, diabetes and/or metabolic syndrome may affect multiple cognitive functions including expression of APP, amyloid- $\beta$ $(\mathrm{A} \beta)$ peptide and tau hyperphosphorylation - molecular signatures of $\mathrm{AD}$ pathology. In brief, an extraneuronal production of both APP and A $\beta$ peptides including the adipose tissue was demonstrated (25-30). Accordingly, the administration of streptozotocin (STZ), a well known experimental model for diabetes, induces brain insulin resistance and cognitive alterations resembling those in $\mathrm{AD}$ patients (31-33). We have reported that STZ-induced diabetes is associated with changes in NGF levels in both pancreas and brain (34). In effect, STZ treatment became a new experimental tool in studying $\mathrm{AD}$, which is increasingly evaluated as type 3 diabetes $(33,35)$. To focus on the
Table 1. Selected list of neuroadipokines (adipose-derived neuroendocrine factors)

\section{Neuropeptides}

Neuropeptide tyrosine (NPY), Substance P, Calcitonin gene-related peptide

Agouti protein, Adrenomedullin, Somatostatin, Kisspeptin Neuromedin B, Neurotensin, Mineralocorticoid-releasing factors Corticotropin-releasing hormone $(\mathrm{CRH})$, Stresscopin and urocortin (CRH-like peptides)

Apelin, Nesfatin-1, S100B protein

\section{Neurotrophic factors}

Nerve growth factor, Brain-derived neurotrophic factor, Leptin, Adiponectin

Vascular endothelial growth factor, Ciliary neurotrophic factor Glial cell line-derived neurotrophic factor, Insulin-like growth factor-1

Angiopoietin-1, Steroids, Metallothionein-1, -2

\section{Neurotransmitters}

Glutamate, Gamma-aminobutyric acid, Acetylcholine

Table 2. Metabotrophic effects of NGF, BDNF and adiponectin (APN)

NGF shares homology with proinsulin

NGF and BDNF are produced by pancreatic beta cells and exert insulinotropic effect

NGF and BDNF are trophic factors for pancreatic beta cells APN is anti-obesity, anti-diabetogenic, anti-atherogenic adipokine BDNF- and APN -deficient mice develop abnormalities similar to the metabolic syndrome

BDNF and APN improve cognitive processes

NGF up-regulates expression of LDL receptor-related protein

NGF up-regulates expression of PPAR-gamma

NGF inhibits glucose-induced down-regulation of caveolin-1

NGF improves skin and corneal wound healing

NGF and APN improve vascular (atheroma) wound healing

NGF rescues silent myocardial ischemia in diabetes mellitus

NGF improves diabetic erectile dysfunction

Healthy lifestyle increases brain and/or circulating levels of NGF, BDNF, APN

Atherogenic diet decreases brain BDNF levels 
brain-metabolism link (36-55) the concept of cognitive diabetes and brain diabetes was recently introduced (56, 57; for the antidiabetic drug metformin and APP processing, see 58, 59). Again, many studies demonstrated that the adipokine leptin has a "therapeutic" effect on the APP processing and tau phosphorylation (16-24).

As mentioned above, $\mathrm{AD}$ is characterized by the accumulation of $\mathrm{A} \beta$ and hyperphosphorylated tau, a microtubule-associated protein. The deposit of $A \beta$ is a result of an imbalance between $\mathrm{A} \beta$ production and clearance. Among several proteases involved in the proteolysis of $A \beta$, neprilysin (neutral endopeptidase, $\mathrm{NEP}$ ), a type II membrane-associated metalloendopeptidase, appears to be the most important $A \beta$-degrading enzyme in the brain, thus exploration of possibilities for NEP delivery is required. Accordingly, it was reported that human adipose tissue-derived stem cells (ADSC) secrete exosomes carrying enzymatically active NEP. When ADSC-derived exosomes were transferred into cultured nerve cells a decrease both secreted and intracellular $A \beta$ levels in the treated cells was found (60), suggesting the therapeutic relevance of these extracellular signaling vesicles for $\mathrm{AD}$.

Altogether, our hypothesis of adipose tissue as a third brain working in tandem with that located "within the head" (Greek, enkephalon), herein referred to as adipose $A D$, might sound more plausible at present.

Further, diabetes mellitus and $\mathrm{AD}$ are both common and increasing incidence in the aging population. Recent evidence has demonstrated common pathogenic factors operating in both conditions. Some proof-of-hypothesis of adipose $A D$ may also derive from the results demonstrating that the circulating and/or tissue levels of NGF, BDNF and adiponectin are commonly decreased in both cardiometabolic and neuropsychiatric diseases, including AD (reviewed in 3,4,15). Thus, adipobiology of the brain has emerged as a challenging area of biomedical research. Its relevance to brown adipose tissue (BAT) also requires research attention.

\section{Conclusion}

The present Dance Round suggests that understanding precisely the neuro-adipose interactions $(61,62)$ may provide new insights in the pathogenesis and the therapy of obesity, diabetes, metabolic syndrome and AD. Further studies may lead to or exclude the possibility that adipose tissue also „suffers” from AD, or at least extend our knowledge of viewing $\mathrm{AD}$ as a metabotrophin-deficient disorder, as previously proposed for obesity and related diseases $(63,64)$.

In 1999 Albee Messing published in Hepatology (29: 602-603) an editorial entitled "Nestin in the liver - lessons from the brain."
He wrote: "Most neuroscientists manage to get through each day without thinking of the liver even once... but I think that is about to change." This may also be the case for adipose tissue.

Today, physicians must accordingly be aware of the increased risk of cognitive deficit in patients with cardiometabolic diseases. And vice versa, to look for alteration of glucose, lipid and adipokine metabolism in patients with $\mathrm{AD}$. Moreover, recent genome wide association study (GWAS) findings provide information for the design of future novel therapeutic approaches for a subpopulation of type 2 diabetic subjects with genetic disposition to $\mathrm{AD}$, that could benefit diabetes and reduce the risk for subsequent development of AD dementia (55).

Of note, after Alois Alzheimer's clinical report of "presenile dementia" on 3 November 1906, the first Italian contributions to the histopathological and clinical description of AD dementia was published by Gaetano Perusini in three papers between 1906 and 1911 (Lucci B. The contribution of Gaetano Perusini to the definition of Alzheimer's disease. Ital J Neurol Sci 1998; 19: 49-52). To appreciate the contribution of Perusini, our hypothesis should be named adipose Alzheimer-Perusini's disease.

\section{Acknowledgements}

None of this review article would have been possible without the staunch support and creative collaboration of our brainand-heart friends (BHF) Peter Ghenev, Danko Georgiev, Marcia Hiriart, Stanislav Yanev, Francesco Angelucci and many others. We apologise to the authors who were not quoted in this text, as their work was omitted for the sake of this Dance Round.

\section{Conflict of interest}

The authors declare no conflict of interest.

\section{References}

1. Yi C-X, Tschöp MH. Brain-gut-adipose tissue communication pathways at a glance. Dis Models Mech 2012; 5: 583-587.[DOI: 10.1242/dmm.009902]

2. Hassanzadeh P. Tissue engineering and growth factors: updated evidence. Biomed Rev 2012; 23: 19-35. [DOI: http://dx.doi.org/10.14748/bmr.v23.26]

3. Triaca V. Homage to Rita Levi-Montalcini. Molecular mechanisms of Alzheimer's disease: NGF modulation of APP processing. Adipobiology 2013; 5: 7-18. [DOI: 10.14748/ adipo.v5.292]

4. Yanev S, Aloe L, Fiore M, Chaldakov GN. Neurotrophic and metabotrophic potential of nerve growth factor and brainderived neurotrophic factor: Linking cardiometabolic and neuropsychiatric diseases. World J Pharmacol 2013; 2: 9299. [DOI: 10.5497/wjp.v2.i4.92] 
5. O’Neill C, Kiely AP, Coakley MF, Manning S, Long-Smith CM. Insulin and IGF-1 signalling: longevity, protein homoeostasis and Alzheimer's disease. Biochem Soc Trans 2012; 40: 721-727. [DOI: 10.1042/BST20120080]

6. Chaldakov GN, Stankulov IS, Hristova MG, Ghenev PI. Adipobiology of disease: adipokines and adipokine-targeted pharmacology. Curr Pharm Des 2003; 9: 1023-1031. [DOI: 10.2174/1381612033455152]

7. Renes J, Mariman E. Application of proteomics technology in adipocyte biology. Mol Biosyst 2013; 9: 1076-1091. [DOI: $10.1039 / \mathrm{c} 3 \mathrm{mb} 25596 \mathrm{~d}]$

8. Kiliaan AJ, Arnoldussen IA, Gustafson DR. Adipokines: a link between obesity and dementia? Lancet Neurol 2014; 13 : 913-923. [DOI: 10.1016/S1474-4422(14)70085-7]

9. Wedrychowicz A, Zajac A, Pilecki M, Koscielniak B, Tomasik PJ. Peptides from adipose tissue in mental disorders. World J Psychiatry 2014; 4: 103-111. [DOI: 10.5498/wjp. v4.i4.103]

10. Beumer W, Drexhage RC, De WH, Versnel MA, Drexhage HA, Cohen D. Increased level of serum cytokines, chemokines and adipokines in patients with schizophrenia is associated with disease and metabolic syndrome. Psychoneuroendocrinology 2012; 37: 1901-1911. [DOI: 10.1016/j. psyneuen.2012.04.001]

11. Sornelli F, Fiore M, Chaldakov GN, Aloe L. Adipose tissuederived nerve growth factor and brain-derived neurotrophic factor: results from experimental stress and diabetes. Gen Physiol Biophys 2009; 28: 179-183. [DOI: PMID: 19893098]

12. Aloe L, Levi-Montalcini R. Mast cells increase in tissues of neonatal rats injected with the nerve growth factor. Brain Res 1977; 133: 358-366. [DOI: 00068993(77)90772-7]

13. Brennan AM, Fargnoli JL, Williams CJ, Li T, Willett W, Kawachi I, et al. Phobic anxiety is associated with higher serum concentrations of adipokines and cytokines in women with diabetes. Diabetes Care 2009; 32: 926-931. [DOI: 10.2337/dc08-1979]

14. Warren MW, Hynan LS, Weiner MF. Lipids and adipokines as risk factors for Alzheimer's disease. J Alzheimers.Dis. 2012; 29: 151-157. [DOI: 10.3233/JAD-2012-111385]

15. Song J, Lee JE. Adiponectin as a new paradigm for approaching Alzheimer's disease. Anat Cell Biol 2013; 46: 229234. [DOI: 10.5115/acb.2013.46.4.229]

16. Signore AP, Zhang F, Weng Z, Gao YQ, Chen J. Leptin neuroprotection in the central nervous system: Mechanisms and therapeutic potentials. J Neurochem 2008; 106: 19771990. [DOI: 10.1111/j.1471-4159.2008.05457.x]

17. Tezapsidis N, Johnston JM, Smith MA, Ashford JW, Casadesus G, Robakis NK, et al. Leptin: a novel therapeutic strategy for Alzheimer's disease. J Alzheimers Dis 2009;16: 731-740. [DOI: 10.3233/JAD-2009-1021]

18. Greco SJ, Sarkar S, Casadesus G, Zhu X, Smith MA, Ashford JW, et al. Leptin inhibits glycogen synthase kinase-3beta to prevent tau phosphorylation in neuronal cells. Neurosci Lett 2009; 455: 191-194. [DOI: 10.1016/j. neulet.2009.03.066]

19. Greco SJ, Sarkar S, Johnston JM, Tezapsidis N. Leptin regulates tau phosphorylation and amyloid through AMPK in neuronal cells. Biochem Biophys Res Commun 2009; 380: 98-104. [DOI: 10.1016/j.bbrc.2009.01.041]

20. Ghasemi M, Zendehbad B, Zabihi H, Hosseini M, Hadjzadeh MA, Hayatdavoudi P. Beneficial effect of leptin on spatial learning and memory in streptozotocin induced diabetic rats. Balkan Med J [DOI: 10.5152/ balkanmedj.2015.15084]

21. Greco SJ, Bryan KJ, Sarkar S, Zhu X, Smith MA, Ashford JW, et al. Leptin reduces pathology and improves memory in a transgenic mouse model of Alzheimer's disease. $J$ Alzheimers Dis 2010; 19: 1155-1167. [DOI: 10.3233/JAD2010-1308]

22. Lieb W, Beiser AS, Vasan RS, Tan ZS, Au R, Harris TB, et al. Association of plasma leptin levels with incident Alzheimer disease and MRI measures of brain aging. JAMA 2009; 302: 2565-2572. [DOI: 10.1001/jama.2009.1836]

23. Lu XY. The leptin hypothesis of depression: a potential link between mood disorders and obesity? Curr Opin Pharmacol 2007; 7: 648-652. [DOI: 10.1016/j.coph.2007.10.010]

24. Carro EM. Therapeutic approaches of leptin in Alzheimer's disease. Recent Pat CNS Drug Discov 2009; 4: 200-208. [DOI: 10.2174/157488980903150306103527]

25. Lee YH, Tharp WG, Maple RL, Nair S, Permana PA, Pratley $\mathrm{RE}$. Amyloid precursor protein expression is upregulated in adipocytes in obesity. Obesity (Silver Spring) 2008; 16: 14931500. [DOI: 10.1038/oby.2008.267]

26. Wan Z, Mah D, Simtchouk S, Kluftinger A, Little JP. Role of amyloid beta in the induction of lipolysis and secretion of adipokines from human adipose tissue. Adipocyte 2015; 4: 212-216. [DOI: 10.4161/21623945.2014.985020]

27. Truran S, Franco DA, Roher AE, Beach TG, Burciu C, Serrano $G$, et al. Adipose and leptomeningeal arteriole endothelial dysfunction induced by beta-amyloid peptide: a practical human model to study Alzheimer's disease vasculopathy. $J$ Neurosci Methods 2014; 235: 123-129. [DOI: 10.1016/j.jneumeth.2014.06.014]

28. Puig KL, Combs CK. Expression and function of APP and its metabolites outside the central nervous system. Exp Gerontol 2013; 48: 608-611. [DOI: 10.1016/j.exger.2012.07.009] 
29. Puig KL, Floden AM, Adhikari R, Golovko MY, Combs CK. Amyloid precursor protein and proinflammatory changes are regulated in brain and adipose tissue in a murine model of high fat diet-induced obesity. PLoS One 2012; 7: e30378. [DOI: 10.1371/journal.pone.0030378]

30. Freeman LR, Zhang L, Dasuri K, Fernandez-Kim SO, Bruce-Keller AJ, Keller JN. Mutant amyloid precursor protein differentially alters adipose biology under obesogenic and non-obesogenic conditions. PLoS.One. 2012; 7: e43193. [DOI: 10.1371/journal.pone.0043193]

31. Wang X, Yu S, Hu JP, Wang CY, Wang Y, Liu HX, et al. Streptozotocin-induced diabetes increases amyloid plaque deposition in $\mathrm{AD}$ transgenic mice through modulating AGEs/ RAGE/NF-B pathway. Int J Neurosci 2014; 124: 601-608. [DOI: 10.3109/00207454.2013.866110]

32. Shingo AS, Kanabayashi T, Kito S, Murase T. Intracerebroventricular administration of an insulin analogue recovers STZ-induced cognitive decline in rats. Behav Brain Res 2013; 241: 105-111. [DOI: 10.1016/j.bbr.2012.12.005]

33. Lester-Coll N, Rivera EJ, Soscia SJ, Doiron K, Wands JR, de la Monte SM. Intracerebral streptozotocin model of type 3 diabetes: relevance to sporadic Alzheimer's disease. $\mathrm{J} \mathrm{Al}$ zheimers Dis 2006; 9: 13-33. [DOI: PMID: 16627931]

34. Sposato V, Manni L, Chaldakov GN, Aloe L. Streptozotocininduced diabetes is associated with changes in NGF levels in pancreas and brain. Arch Ital.Biol 2007; 145: 87-97. [DOI: 10.3109/00207454.2013.866110]

35. de la Monte SM, Wands JR. Alzheimer's disease is type 3 diabetes - evidence reviewed. J Diab Sci Technol 2008; 2: 1101-1113. [DOI: PMC2769828]

36. Sridhar GR, Lakshmi G, Nagamani G. Emerging links between type 2 diabetes and Alzheimer's disease. World J Diabetes 2015 ; 6. [DOI: 10.4239/wjd.v6.i5.1]

37. Dar A, Sheikh A, Ganie A, Ali R, Singh R, Gan SH, et al. Molecular linkages between diabetes and Alzheimer's disease: Current scenario and future prospects. CNS Neurol Disord - Drug Targets 2014; 13: 290-298. [DOI: 10.2174/18715273113126660135]

38. Rios JA, Cisternas P, Arrese M, Barja S, Inestrosa NC. Is Alzheimer's disease related to metabolic syndrome? A Wnt signaling conundrum. Prog Neurobiol 2014; 121: 125-146. [DOI: 10.1016/j.pneurobio.2014.07.004]

39. Jackson HM, Soto I, Graham LC, Carter GW, Howell GR. Clustering of transcriptional profiles identifies changes to insulin signaling as an early event in a mouse model of Alzheimer's disease. BMC.Genomics 2013; 14: 831. [DOI: 10.1186/1471-2164-14-831]

40. Luchsinger JA, Mayeux R. Adiposity and Alzheimer's disease. Curr Alzheimer Res 2007; 4: 127-134. [DOI: $10.2174 / 156720507780362100$ ]

41. Naderali EK, Ratcliffe SH, Dale MC. Obesity and Alzheimer's disease: a link between body weight and cognitive function in old age. Am.J Alzheimers Dis Other Demen 2009; 24: 445-449. [DOI: 10.1177/1533317509348208]

42. de la Monte SM. Brain insulin resistance and deficiency as therapeutic targets in Alzheimer's disease. Curr Alzheimer Res 2012; 9: 35-66. [DOI: 10.2174/156720512799015037]

43. Hildreth KL, Van Pelt RE, Schwartz RS. Obesity, insulin resistance, and Alzheimer's disease. Obesity (Silver.Spring) 2012; 20: 1549-1557. [DOI: 10.1038/oby.2012.19]

44. Arnoldussen IA, Kiliaan AJ, Gustafson DR. Obesity and dementia: adipokines interact with the brain. Eur Neuropsychopharmacol 2014; 24: 1982-1999. [DOI: 10.1016/j.euroneuro.2014.03.002]

45. Strittmatter WJ. Alzheimer's disease: the new promise. $J$ Clin Invest 2012; 122: 1191. [DOI: 10.1172/JCI62745]

46. Sebastiao I, Candeias E, Santos MS, de Oliveira CR, Moreira PI, Duarte AI. Insulin as a bridge between type 2 diabetes and Alzheimer disease - How anti-diabetics could be a solution for dementia. Front Endocrinol (Lausanne) 2014; 5: 110. [DOI: 10.3389/fendo.2014.00110]

47. Biessels GJ, Staekenborg S, Brunner E, Brayne C, Scheltens $\mathrm{Ph}$. Risk of dementia in diabetes mellitus: a systematic review. Lancet Neurol 2006; 5: 64-74. [DOI: 10.1016/S14744422(05)70284-2]

48. Sima AA, Li ZG. Diabetes and Alzheimer's disease - is there a connection? Rev Diabet Stud 2006; 3: 161-168. [DOI: 10.1900/RDS.2006.3.161]

49. Li L, Holscher C. Common pathological processes in Alzheimer disease and type 2 diabetes: a review. Brain Res Rev 2007; 56: 384-402. [DOI: 10.1016/j.brainresrev.2007.09.001]

50. Sjogren M, Blennow K. The link between cholesterol and Alzheimer's disease. World J Biol Psychiatry 2005; 6: 85-97.

51. Sun MK, Alkon DL. Links between Alzheimer's disease and diabetes. Drugs Today (Barc) 2006; 42: 481-489. [DOI: 10.1358/dot.2006.42.7.973588]

52. Giordano V, Peluso G, Iannuccelli M, Benatti P, Nicolai R, Calvani M. Systemic and brain metabolic dysfunction as a new paradigm for approaching Alzheimer's dementia. Neurochem Res 2007; 32: 555-567. [DOI: 10.1007/s11064-0069125-8]

53. Manning S. Diabetes and dementia: a common link or coincidental coexistence. Biomed Rev 2007; 18: 59-64. [DOI: http://dx.doi.org/10.14748/bmr.v18.68]

54. Erol A. An integrated and unifying hypothesis for the metabolic basis of sporadic Alzheimer's disease. J Alzheimers Dis 2008;13:241-253. 
55. Hao K, Di Narzo AF, Ho L, Luo W, Li S, Chen R, et al. Shared genetic etiology underlying Alzheimer's disease and type 2 diabetes. Mol Aspects Med 2015; 43-44: 66-76. [DOI: 10.1016/j.mam.2015.06.006]

56. Shingo AS, Mervis RF, Kanabayashi T, Kito S, Murase T. The dendrites of granule cell layer neurons are the primary injury sites in the "Brain Diabetes" rat. Behav Brain Res 2015; 280: 78-83. [DOI: 10.1016/j.bbr.2014.11.041]

57. Frisardi V, Solfrizzi V, Seripa D, Capurso C, Santamato A, Sancarlo D, et al. Metabolic-cognitive syndrome: a crosstalk between metabolic syndrome and Alzheimer's disease. Ageing Res Rev 2010; 9: 399-417. [DOI: 10.1016/j. arr.2010.04.007]

58. Chen Y, Zhou K, Wang R, Liu Y, Kwak YD, Ma T, et al. Antidiabetic drug metformin (GlucophageR) increases biogenesis of Alzheimer's amyloid peptides via up-regulating BACE1 transcription. Proc.Natl.Acad.Sci U.S.A 2009; 106: 3907-3912. [DOI: 10.1073/pnas.0807991106]

59. Moore EM, Mander AG, Ames D, Kotowicz MA, Carne $\mathrm{RP}$, Brodaty $\mathrm{H}$, et al. Increased risk of cognitive impairment in patients with diabetes is associated with metformin. Diabetes Care 2013; 36: 2981-2987. [DOI: 10.2337/ dc13-0229]
60. Katsuda T, Tsuchiya R, Koska N, Yoshioka Y, Takagaki K, Oki K, et al. Human adipose tissue-derived mesenchymal stem cells secrete functional neprilysin-bound exosomes. Sci Rep 2013; 3, Article number: 1197. [DOI: 10.1038/ srep01197]

61. Chaldakov GN, Aloe L, Tonchev AB, Chervenkov T, Fiore M, Zhelezov M. Neuro-adipose interactions (biactome). Implication in cardiometabolic disease. Proc Rom Acad Series B 2014; 16:133-141.

62. Chaldakov GN, Fiore M, Ghenev PI, Beltowski J, Rancic $\mathrm{G}$, Tuncel N, et al. Triactome: neuro-immune-adipose interactions. Implication in vascular biology. Front Immunol 2014; 5: 130. [DOI: 10.3389/fimmu.2014.00130]

63. Chaldakov GN, Fiore M, Tonchev AB, Dimitrov D, Pancheva R, Rancic G, Aloe L. Homo obesus: a metabotrophindeficient species. Pharmacology and nutrition insight. Curr Pharm Des 2007; 13: 2176-2179.

64. Chaldakov GN, Tonchev AB, Aloe L. NGF and BDNF: from nerves to adipose tissue, from neurokines to metabokines. Riv Psichiatr 2009;44:79-87. 